\title{
Pregnancy-Related Peritoneal Ectopic Decidua (Deciduosis): Morphological and Clinical Evaluation
}

\author{
Gebelik ile İlişkili Peritoneal Ektopik Desidua (Desiduozis): \\ Morfolojik ve Klinik Değerlendirme
}

Filiz BOLAT ${ }^{1}$, Tuba CANPOLAT ${ }^{1}$, Ebru TARIM ${ }^{2}$

Departments of ${ }^{1}$ Pathology and ${ }^{2}$ Obstetrics and Gynaecology, Başkent University, Faculty of Medicine, ANKARA, TURKEY

\begin{abstract}
Objective: Ectopic decidual reaction (deciduosis) can be seen rarely on the peritoneum during laparotomy for a cesarean section for pregnancy, in addition to the ovary and cervix. The aim of this study was to evaluate the clinical, histopathological, immunohistochemical characteristics of ectopic decidua cases that were incidentally found in the peritoneum during a cesarean section.
\end{abstract}

Material and Method: A total of seven cases where decidualization was found in the peritoneal biopsy taken during pregnancy at the Baskent University Adana Research and Medical Center, Department of Pathology were included in this study. The clinical features of the cases were obtained from their clinical folders. The morphological findings were recorded and the peritoneal biopsies were analyzed with keratin Pan Ab-1, calretinin, vimentin, HMB-45 and progesterone receptor antibody for immunohistochemical analysis.

Results: The mean age for the seven cases was $36 \pm 4.16$. The gestational age was 33 to 39 (mean 37.2) weeks. Microscopic evaluation revealed decidualized cells that were large polygonal and eosinophilic, some with vacuolated cytoplasm, that formed small nodules under the mesothelium of the peritoneum in all cases. Immunohistochemical staining showed positive staining of the cell cytoplasm with vimentin and positive staining of the cell nucleus with the progesterone receptor antibody in the decidual cells. Calretinin, keratin and HMB-45 stains were negative.

Conclusion: Pregnancy-related peritoneal deciduosis develops with the effect of progesterone in pregnancy. It disappears without complication in the postpartum period. Immunohistochemistry may help the differential diagnosis of peritoneal deciduosis where problems are experienced differentiating the case from malignant mesothelioma or metastatic tumor.

Key Words: Decidua, Ectopic tissue, Pregnancy

\begin{abstract}
ÖZ
Amaç: Ektopik desidual reaksiyon (desiduozis), over ve serviks yanı sıra, gebelikte sezaryan sırasında laporatomide nadiren peritonda da görülebilir. Bu çalışmada sezaryan sırasında peritonda insidental olarak saptanan ektopik desidua olgularının klinik, histopatolojik, immünohistokimyasal özelliklerinin araştırılması amaçlandı.
\end{abstract}

Gereç ve Yöntem: Bu çalışmaya Başkent Üniversitesi Tıp Fakültesi Adana Uygulama ve Araştırma Hastanesi Patoloji Anabilim Dalı'nda, gebelik sırasında alınan peritoneal biyopsilerde desidualizasyon saptanan yedi olgu dahil edildi. Bu olgulara ait klinik bulgular hasta dosyalarından elde edildi. Morfolojik bulgular kaydedildi ve periton biyopsilerine immünohistokimyasal inceleme ile keratin Pan Ab-1, kalretinin, vimentin, HMB-45 ve progesteron reseptör antikoru uygulandi.

Bulgular: Yedi olgunun yaş ortalaması $36 \pm 4.16$ dır. Hastalar 33-39 (ortalama 37.2 hafta) gebelik haftasındaydı. Mikroskopik incelemede olguların tümünde peritonda mezotel altında çoğunlukla küçük nodüller oluşturan, büyük poligonal eozinofilik, bir kısmı vakuole sitoplazmall, desidualize hücreler izlendi. İmmünohistokimyasal incelemede, desidual hücrelerde vimentin ile hücre sitoplazmalarında ve progesteron reseptörü antikoru ile de hücre nükleusunda pozitif boyanma saptand. Kalretinin, keratin ve HMB-45 boyaları negatif bulundu.

Sonuç: Gebelik ile ilişkili peritoneal desiduozis, gebelikteki progesteron hormonunun etkisiyle oluşur. Gebelik sonrası dönemde komplikasyon olmadan kaybolur. Özellikle malign mezotelyoma ve metastatik tümor ayrımında, sorun yaşanan olgularda peritoneal desiduozisin ayırıcı tanısında immunohistokimya yardımcı olabilir.

Anahtar Sözcükler: Desidua, Ektopik doku, Gebelik

Correspondence: Filiz BOLAT

Department of Pathology, Başkent University, Adana Research and Medical Center, ADANA, TURKEY

E-mail: drfilizbolat@yahoo.com Phone: +90 3223272727 


\section{INTRODUCTION}

Decidual cell groups outside the endometrium are named "ectopic decidua" or "deciduosis" and this condition has first been defined by Walker in 1887 (1). Ectopic decidua is most commonly localized in the ovary, cervix and uterine serosa (2-5) while the peritoneal localization is rare (6-10). It generally has no clinical symptoms.

It is believed that peritoneal deciduosis develops as a result of the metaplasia of subserosal stromal cells with the effect of the progesterone hormone during pregnancy and it regresses within the 4-6 weeks duration after pregnancy with decidual involution. It therefore requires no therapeutic intervention and disappears without complication in the postpartum period $(7,9,11)$.

It is necessary to perform a differential diagnosis between perioteal deciduosis and mesothelioma, metastatic carcinoma and metastatic malignant melanoma and identifying decidual tissue is therefore important from the clinical and pathological point of view (9-13).

\section{MATERIAL and METHODS}

We present seven cases where decidualization was found in the peritoneal biopsies obtained during pregnancy at the Baskent University Adana Research and Medical Center, Department of Pathology in this study. We evaluated the folders of the cases to look for the gestational age, clinical history of endometriosis and/or the presence of endometriosis symptoms.

The peritoneal biopsy samples were fixed in $10 \%$ buffered formaldehyde and then embedded in paraffin followed by taking hematoxylin-eosin stained section 5 microns thick and evaluating the sections with light microscopy. In microscopic analysis of the biopsy samples, the characteristics of the cells were evaluated; whether they contained atypia and/or mitotic activity, cell distribution (diffuse or nodular), the presence of inflammatory cells, the presence of old or new hemorrhagic foci, presence of endometrial gland or stroma, and granulomatous structure on the peritoneal biopsy. Immunohistochemical studies were used for the diagnosis and differential diagnosis of all samples where decidual cells were observed in the peritoneum.

The immunohistochemical investigation was done by using standard immunoperoxidase $\mathrm{ABC}$ (avitin-biotinpreroxidase complex) technique for keratin Pan Ab-1 (7.0 $\mathrm{ml}$, ready-to-use, catalog MS-343-R7, Thermo Scientific, Fremont CA, USA), calretinin (dilution 1:100, clone CRT01, SC-5709, Santa Cruz, Fremont CA, USA), vimentin $(7.0 \mathrm{ml}$, ready-to-use, clone V9, NeoMarkers, Fremont CA, USA), HMB-45 (ready-to-use, code N1545, LBAS kit,
DAKO, Glostrup, Denmark) and Progesterone receptor (PR) antibody (7.0 ml, ready-to-use, catalog RM-9102-R7, Thermo Scientific, Fremont CA, USA) application.

On immunohistochemical evaluation, brownish red cytoplasmic staining with keratin, calretinin, vimentin and HMB-45 was considered positive while brownish red nuclear staining was considered positive for PR.

\section{RESULTS}

The mean age of the 7 cases was $36 \pm 4.16$ (31-43) and the gestational age was 33-39 (mean 37.2) weeks. There was no history of endometriosis or any of its symptoms in the clinical history of the patients. The biopsy was taken from a lesion that looked like a small nodule on the peritoneum during cesarean section in three cases, while a biopsy had been sent from areas with peritoneal adhesions in the other cases. Macroscopic evaluation of the peritoneal biopsies revealed a single yellow nodule $1-4 \mathrm{~mm}$ in diameter on the peritoneum in three cases. There was no significant nodular lesion macroscopically in the other four cases.

Microscopic analysis of the samples showed single nucleus decidualized cells, that were large polygonal and eosinophilic (Figure 1) or some with vacuolated cytoplasm, that mostly created small nodules under the mesothelium in the peritoneum (Figure 2). No nuclear pleomorphism, hyperchromasia or mitotic activity was found in the decidual cells. Two cases had mild lymphocytic infiltration and lymphoid aggregates in the decidual foci but no granulomatous structure was seen. Immunohistochemical evaluation showed positive staining in the decidual cell cytoplasm with vimentin (Figure 3) and positive staining with progesterone receptor antibody in the cell nucleus (Figure 4) of decidual cells while the results of the calretinin (Figure 5), keratin (Figure 6) and HMB-45 stains for differential diagnosis were negative.

\section{DISCUSSION}

Extrauterine or ectopic decidua is most commonly seen in the ovaries, cervix, uterine serosa and the lamina propria of the tuba uterina, while a peritoneal localization is rare for decidua $(2-6,11)$. It is less commonly seen in the appendix, omentum, diaphragm, liver, spleen, paraaortic-pelvic lymph nodes and renal pelvis (11,14-17).

Most ectopic decidua cases are related to normal pregnancy as in our case (6-8). It has been reported to be associated with a progesterone-secreting active corpus luteum or the adrenal cortex in non-pregnant or post-menopausal women (9). Peritoneal ectopic decidua is found incidentally in biopsies obtained during a cesarean section, tubal pregnancy, elective tubal ligation and appendectomy. However it can also been together with hemoperitoneum (18), abdominal 


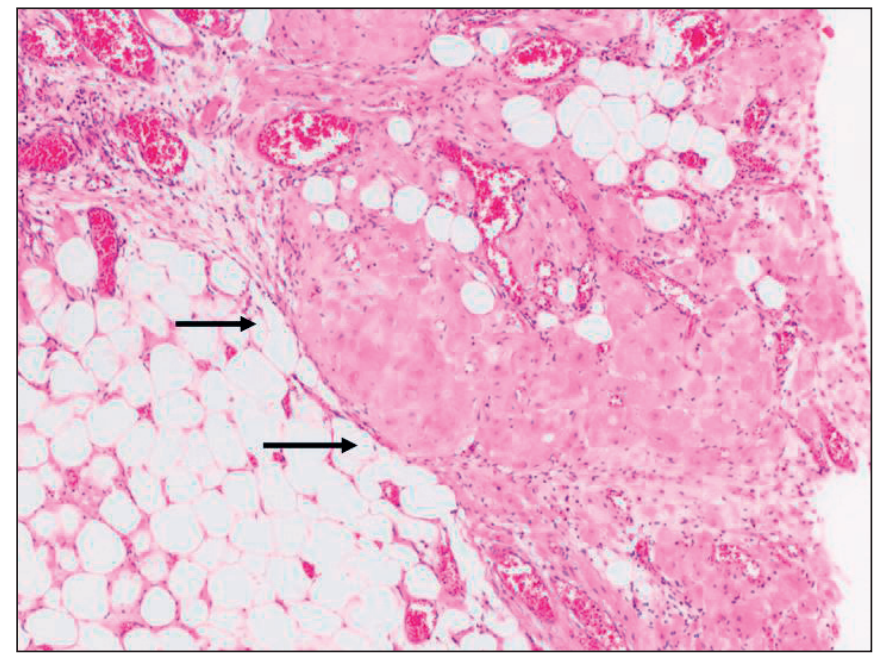

Figure 1: Polygonal-shaped decidual cell island in the submesothelial area (arrows) (H\&E, x100).

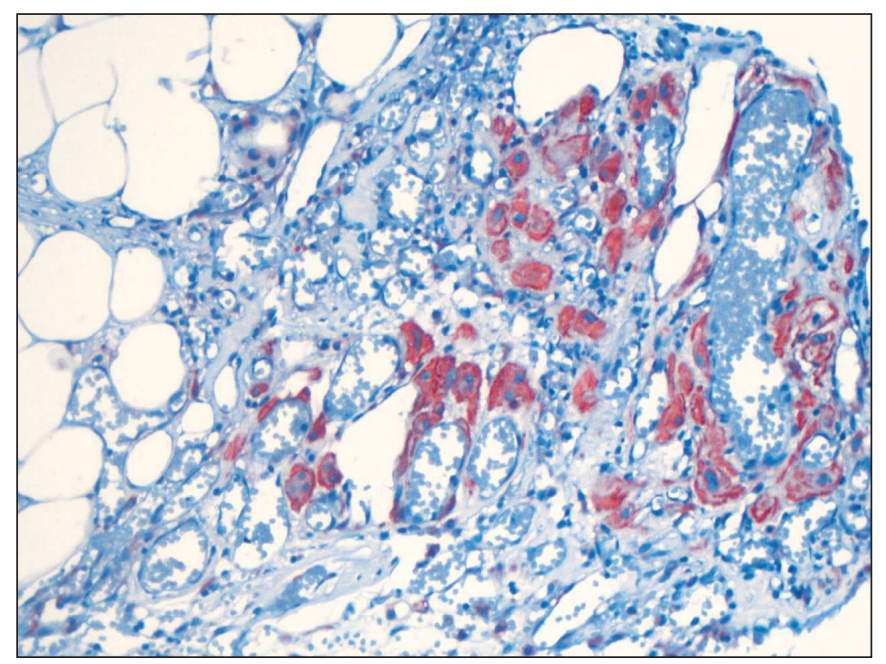

Figure 3: Vimentin positivity in the decidual cells (x200).

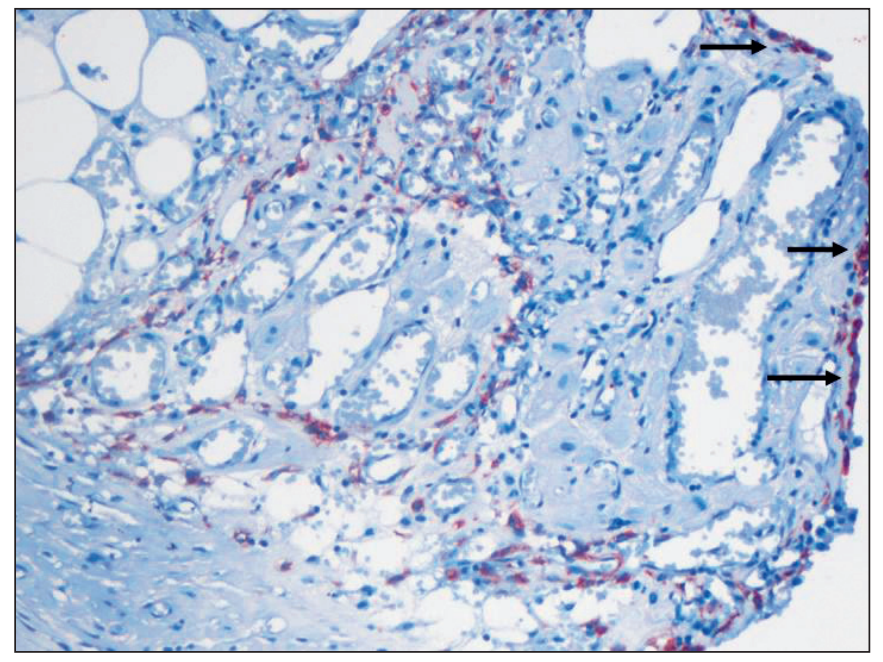

Figure 5: Calretinin positive mesothelial cells on the surface (arrows), negative staining of decidual cells (x200).

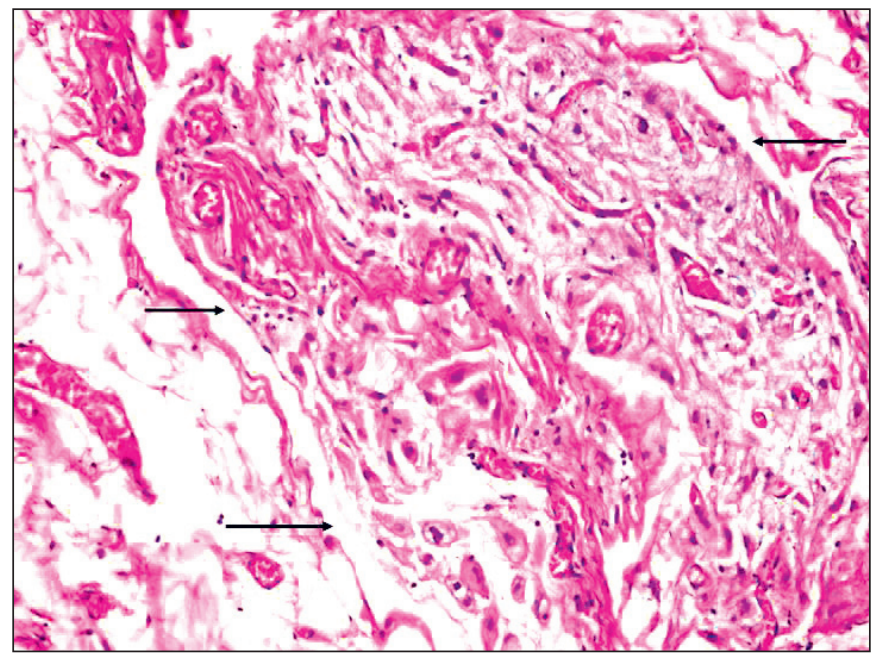

Figure 2: Decidual cell groups with vacuolated cytoplasm in the myxoid stroma in the peritoneum (arrows) (H\&E, x200).

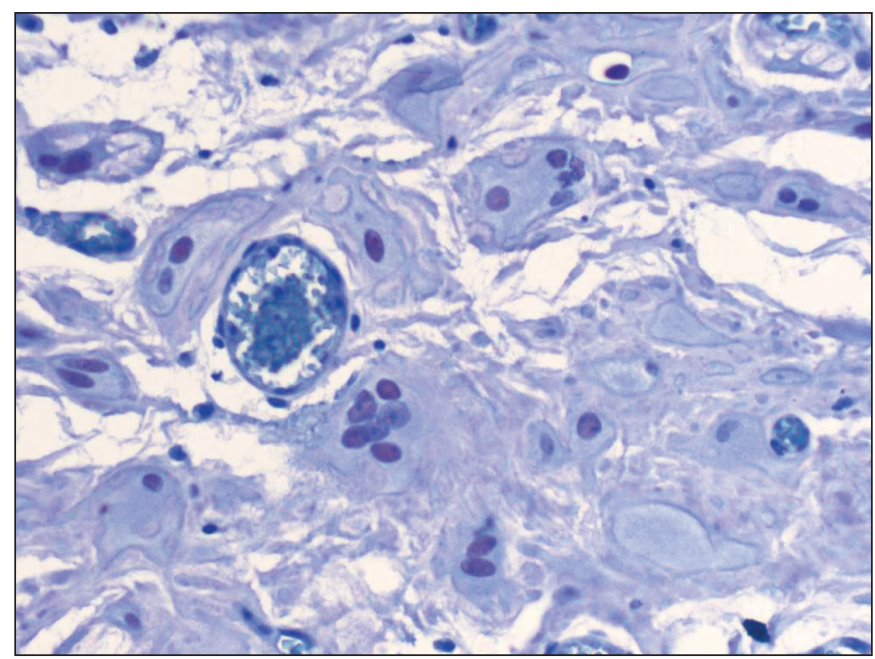

Figure 4: Progesterone receptor positivity in the decidual cells (x400).

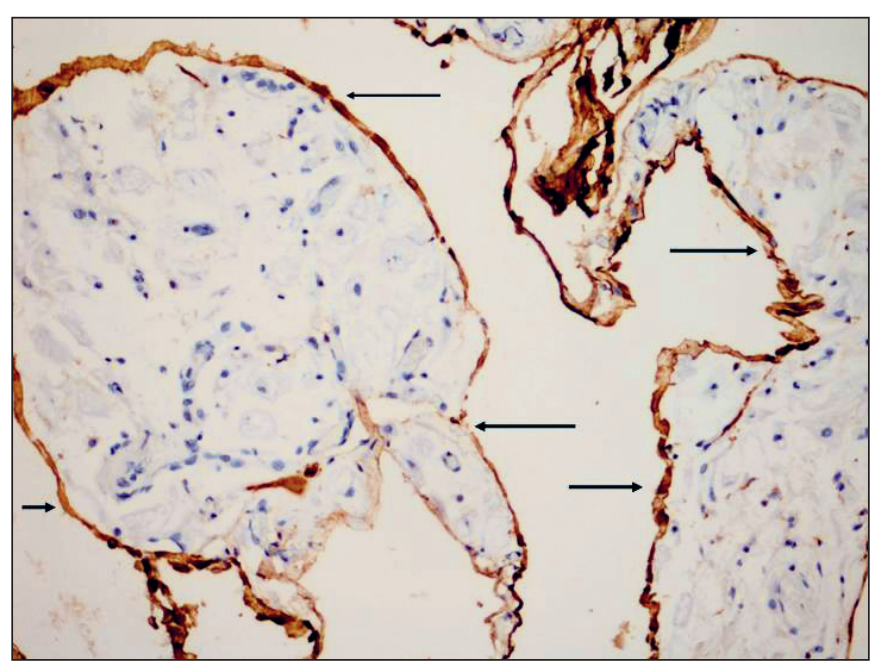

Figure 6: Keratin-positive mesothelial cells on the surface (arrows), negative staining in the decidual cells (x200). 
pain mimicking appendicitis $(14,15)$, hydronephrosis due to renal pelvis involvement or symptoms such as hematuria or with life-threatening complications such as mechanical ileus $(11,17)$. Our cases did not have any clinical symptom and the decidual tissue was found incidentally.

The macroscopic appearance of peritoneal ectopic decidua is variable and it may have an individual geographic pattern, nodular distribution or polypoid appearance $(7,9)$. Our cases were in the form of a single small nodule found incidentally on the peritoneum.

Ectopic deciduosis on the omentum is in the form of focal deciduosis or diffuse deciduosis. Florid lesions are seen on the peritoneal surface as multiple, gray-white, focal hemorrhagic nodules or plaques and are detected during surgery; they are frequently confused with peritoneal tuberculosis or metastatic lesions and can cause a problem in frozen sections $(6,7,9-13)$.

Microscopically, decidual cells are generally found under the mesothelium, in the subcoelomic mesenchyme or in fatty tissue. The lesions are found as small cell groups or single cell clusters in the peritoneum in $97 \%$ of the cases, while they are in the form of widespread-diffuse deciduosis that completely fills the fatty tissue in $3 \%$ of the cases $(7,9)$. The decidual cells were in the submesothelial area and in the form of small cell groups and isolated cell clusters in fatty tissue in our cases as well.

Decidual cells are generally large polygonal, with homogeneous, eosinophilic cytoplasm and vacuolar degeneration at various rates can be seen in these cells. Decidual vacuolization is related to the duration of the pregnancy and the stroma may contain a myxoid deposit due to vacuole rupture if the decidual cell cytoplasm vacuolar degeneration is over $50 \%$ (9). Vacuolated decidual cells and a myxoid stroma was seen in two of our cases and they were at the 38th week of pregnancy.

The pathogenesis of ectopic decidual reactions are not yet fully understood and it is controversial whether it is a physiological reaction or pathological process. It is said to be the result of the exaggerated response of the endometrium to progesterone during pregnancy and Zaystev et al. have suggested two related theories (7). The most commonly accepted theory is the metaplasia of the sub-coelomic pluripotent mesenchymal cells with the effect of progesterone. The fact that the lesion resolves once the hormonal stimulus ends supports this theory. Another theory is "de novo" development of peritoneal decidual cells.

Endometriotic foci undergo marked stromal decidualization with the effect of progesterone during pregnancy and this resembles ectopic decidua. It is therefore necessary to differentiate deciduosis from decidualized endometriosis clinicopathologically. The presence of clinical symptoms at the beginning of the menstrual period and the presence of endometriosis foci in other areas is important for cases with a clinical picture of endometriosis $(7,8)$. Our cases did not have clinical endometriosis symptoms or history. Histologically, the diffuse distribution of the peritoneal lesion, edema of the decidualized stroma, old and new hemorrhagic foci, "pseudoxanthoma cells" and fibrosis signifying endometrial gland atrophy, the AriasStella reaction are important in diagnosis the decidual transformation of endometriosis foci in pregnancy, i.e. decidualized endometriosis (8). The peritoneal deciduosis tissues did not show diffuse distribution in our cases and there were no old or new hemorrhagic foci or endometrial glands and/or stroma. The cases were therefore interpreted as pregnancy-related ectopic decidua.

On microscopy it isimportant to differentiate ectopic decidua with decidual cells showing varying degrees of nuclear pleomorphism and hyperchromasia and focal hemorrhagic necrosis areas with deciduoid malignant mesothelioma and metastatic malignant melanoma, and ectopic decidual tissue containing myxoid stroma and vacuolated decidual cells from metastatic signet ring cell carcinoma. The clinical history of the patient, the lack of mitosis in decidual cells, and the vimentin and PR positivity and keratin, calretinin, HBME-1 antibody negativity on immunohistochemical analysis support peritoneal deciduosis. Cytokeratin 5/6 and calretinin positivity support deciduoid mesothelioma, the keratin positivity metastatic carcinoma and the HMB-45 and S-100 protein positivity support malignant melanoma $(10,12,13)$.

In conclusion, pregnancy-related ectopic decidual tissue is a benign lesion and resolves without any treatment in the postpartum period and should therefore be kept in mind for the differential diagnosis although it is seen rarely on the peritoneum.

\section{REFERENCES}

1. Walker A: Der Bau der Eihaeute bei Graviditatis abdominalis Virchows Arch Path Anat 1887, 197:72-99

2. Israel SL, Rubenstone A, Meranze Dr: The ovary at term. I. Decidua-like reaction and surface cell proliferation. Obstet Gynecol 1954, 3:399-407

3. Ober WB, Grady HG, Schoenbucher AK: Ectopic ovarian decidua without pregnancy. Am J Pathol 1957, 23:199-217

4. Schneider V, Barnes LA: Ectopic decidual reaction of the uterine cervix: frequency and cytologic presentation. Acta Cytol 1981, 25:616-622

5. Hofbauer J: Decidual formation on the peritoneal surface of the gravid uterus. Am J Obstet Gynecol 1929, 17:603-612 
6. Shukla S, Pujani M, Singh SK: Ectopic decidual reaction mimicking peritoneal tubercles: a report of three cases. Indian J Pathol Microbiol 2008, 51:519-520

7. Zaytsev P, Taxy JB: Pregnancy-associated ectopic decidua. Am J Surg Pathol 1987, 11:526-530

8. Massi D, Susini T, Paglierani M, Salvadori A, Giannini A: Pregnancy-associated ectopic decidua. Acta Obstet Gynecol Scand 1995, 74:568-571

9. Büttner A, Bässler R, Theele C: Pregnancy-associated ectopic decidua (deciduosis) of the greater omentum. An analysis of 60 biopsies with cases of fibrosing deciduosis and leiomyomatosis peritonealis disseminata. Pathol Res Pract 1993, 189:352-359

10. Kondi-Pafiti A, Grapsa D, Kontogianni-Katsarou K, Papadias K, Kairi-Vassilatou E: Ectopic decidua mimicking metastatic lesions-report of three cases and review of the literature. Eur J Gynaecol Oncol 2005, 26:459-461

11. Clement PB: Diseases of the Peritoneum. In Kurman RJ. (Ed): Blaustein's Pathology of the Female Genital Tract. 5th ed., New York, Springer, 2002, 729-789
12. Mourra N, de Chaisemartin C, Goubin-Versini I, Parc R, Flejou JF: Malignant deciduoid mesothelioma: a diagnostic challenge. Arch Pathol Lab Med 2005, 129:403-406

13. Reis-Filho JS, Pope LZ, Milanezi F, Balderrama CM, Serapião MJ, Schmitt FC: Primary epithelial malignant mesothelioma of the pericardium with deciduoid features: cytohistologic and immunohistochemical study. Diagn Cytopathol 2002, 26:117-122

14. Lesaffer J, Feryn T, Proot L: Pregnancy-associated ectopic decidua of the appendix. Acta Chir Belg 2009, 109:93-94

15. Suster S, Moran CA: Deciduosis of the appendix. Am J Gastroenterol 1990, 85:841-845

16. Wu DC, Hirschowitz S, Natarajan S: Ectopic decidua of pelvic lymph nodes: a potential diagnostic pitfall. Arch Pathol Lab Med 2005, 129:e117-120

17. Bettinger HF: Ectopic decidua in the renal pelvis. J Pathol Bacteriol 1947, 59:686

18. O'Leary SM: Ectopic decidualization causing massive postpartum intraperitoneal hemorrhage. Obstet Gynecol 2006, 108:776-769 